\title{
ROLA UNII BANKOWEJ W PROCESIE INTEGRACJI EUROPEJSKIEJ
}

\section{Agata Graczyk ${ }^{*}$}

\section{ROLE OF THE BANKING UNION IN THE EUROPEAN INTEGRATION PROCESS}

\begin{abstract}
The main objective of this article is to assess the impact of the banking union on shaping the integration process on the European continent. This has been done by positioning the banking union as a stage leading to a full union of European countries. The basic research question of this study has been formulated as follows: is the banking union project an important element contributing to the full integration of EU banking systems, the implementation of which is necessary to protect the European Union from the effects of future banking crises? This issue was resolved on the basis of an analysis of the available literature and statistical data. The main conclusion of the research undertaken is that: the banking union is a necessary step towards further European integration and is a key element in the integration of European banking systems. However, even the full implementation of the banking union project will not completely eliminate the possibility of banking crises, but may reduce this risk to some extent and thus reduce the costs of potential crises.
\end{abstract}

Keywords: banking union, European integration, the euro area.

JEL Class: F02, G21.

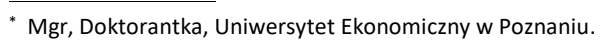




\section{WSTĘP}

Współcześnie obserwuje się zjawisko finansjalizacji gospodarek, co wyraża się we wzroście roli rynku finansowego w kreowaniu produktu krajowego brutto. Tym samym znaczenie sektora bankowego jako głównego gracza na tym rynku wciąż wzrasta. Rozwój technologii informatycznych i telekomunikacyjnych sprawił, że zanikły bariery w swobodnym przepływie kapitałów, a postępująca integracja europejska umożliwiła bankom prowadzenie działalności transgranicznej w coraz większym stopniu. Sytuacja ta rodzi pewne zagrożenia, które zmaterializowały się w czasie minionego kryzysu finansowego. $Z$ powodu silnego uzależnienia poszczególnych systemów finansowych podczas kryzysu w bardzo szybkim tempie niekorzystne zjawiska przenosiły się pomiędzy państwami. W związku z tym zaistniała potrzeba zapobieżenia wystąpienia w przyszłości negatywnych konsekwencji kryzysów bankowych. Celowi temu ma służyć koncepcja unii bankowej tworzona obecnie w ramach Unii Europejskiej.

Niniejszy artykuł dotyczy roli unii bankowej jaką odgrywa ona w procesie integracji europejskiej. W pierwszej części artykułu wyjaśniono pojęcia integracja oraz szczegółowo scharakteryzowano dotychczasowy przebieg procesu integracji na kontynencie europejskim oraz przedstawiono zasady funkcjonowania strefy euro, jako obszaru w którym obligatoryjnie ma działać unia bankowa. Zasadniczym elementem niniejszego artykułu ściśle dotyczącym wdrażanego projektu europejskiej unii bankowej jest prezentacja genezy, istoty i celu poszczególnych filarów zintegrowanych ram finansowych.

\section{DOTYCHCZASOWY PRZEBIEG INTEGRACJI EUROPEJSKIEJ}

Słowo integracja wywodzi się z języka łacińskiego, w którym oznacza odnowienie (Bańkowski, 2000: 275). Potocznie integracja jest rozumiana jako proces łączenia kilku elementów w jednolitą całość. Pojęcie to jest powszechnie stosowane w różnych dziedzinach nauki, lecz zazwyczaj wiąże się z zaawansowanymi formami współpracy danej grupy krajów oraz pochodzących z nich podmiotów ekonomicznych.

W przeszłości na terenie Europy miało miejsce wiele działań o charakterze integracyjnym, których początek sięga czasów starożytnych. Jednak pojęcie integracja europejska z reguły dotyczy procesów zachodzących w Europie po zakończeniu II wojny światowej. Wśród czynników powodujących powstanie idei zjednoczonej Europy należy wymienić chęć państw do odbudowy zniszczeń spowodowanych działaniami wojennymi oraz zapobieżenie konfliktom zbrojnym między państwami europejskimi w przyszłości. Integracja europejska jest procesem wielowymiarowym i obejmuje wiele wydarzeń występujących równolegle, który 
w początkowym okresie obejmował wyłącznie zachodnią część Europy. Cechami wyróżniającymi współczesną integrację europejską od wcześniejszych prób zjednoczenia tego terytorium są: dobrowolność działań oraz samodzielność podejmowania decyzji w tym zakresie przez suwerenne państwa. W 1949 roku w Londynie utworzono Radę Europy, pierwszą powojenną organizację polityczną, której celem było wspieranie międzynarodowej współpracy i jedności w Europie. Nie należy ona do unijnych struktur, ale uważana za "strażnika” demokracji, nazywana jest „,poczekalnią” bądź ,przedpokojem” Unii Europejskiej. Dzieje się tak dlatego, że jeszcze się nie zdarzyło, żeby przyjęto do Wspólnot lub Unii jakieś państwo bez uprzedniego członkostwa w Radzie Europy (Mach i Natanek, 2011: 47, 53-54).

W owym czasie państwa europejskie podjęły również współpracę w sferze obronności, lecz pierwszorzędną rolę w zakresie zjednoczenia Europy odegrało powstanie trzech sektorowych wspólnot europejskich na mocy tzw. traktatów założycielskich. Pierwszą z nich była Europejska Wspólnota Węgla i Stali, której plan utworzenia na podstawie projektu Jean'a Monnet'a w maju 1950 roku przedstawił Robert Schuman. Plan Schumana nawiązywał do idei solidarności europejskiej, a kontrola nad wydobyciem węgla i produkcją stali miała stanowić pierwszy krok ku federacji gospodarki europejskiej. Po trwającej kilka miesięcy konferencji w kwietniu 1951 roku podpisano w Paryżu Traktat powołujący Europejską Wspólnotę Węgla i Stali. Obejmowała ona następujące państwa członkowskie: Francję, Belgię, Holandię, Luksemburg, Włochy oraz RFN. Traktat ten wszedł w życie w lipcu 1952 roku i dotyczył znoszenia barier celnych oraz kontyngentów we wzajemnym obrocie, powodując rozwój wspólnego rynku węgla i stali poprzez specjalizację i zwiększoną wydajność produkcji.Ta sektorowa integracja przemysłu ciężkiego utworzona na okres pięćdziesięciu lat przez sześć sąsiadujących ze sobą państw stanowiła zaczątek zachodnioeuropejskiej integracji i tworzyła wzór organizacyjny dla późniejszych struktur integracyjnych (Łastawski, 2011: 96-103). Drugą wspólnotą europejską była Europejska Wspólnota Gospodarcza, która powstała w 1958 roku. Podstawą jej funkcjonowania stał się podpisany w Rzymie w dniu 25 marca 1957 roku Traktat ustanawiający Europejską Wspólnotę Gospodarczą, którego sygnatariuszami były państwa tworzące Europejską Wspólnotę Węgla i Stali. Podstawowym celem tej organizacji było ustanowienie wspólnego rynku oraz stopniowe upodabnianie polityk gospodarczych krajów członkowskich (Sieniow, 2012: 31-32). Trzecią wspólnotową organizacją stworzoną na podstawie drugiego Traktatu Rzymskiego z 1957 roku jest Europejska Wspólnota Energii Atomowej nazywana potocznie Euratomem. Oba Traktaty Rzymskie zostały zawarte na czas nieograniczony i weszły w życie po ratyfikacji przez sygnatariuszy w początku 1958 roku. Postanowienia Traktatu ustanawiającego Europejską Wspólnotę Energii Atomowej dotyczyły zapewnienia warunków 
dla stworzenia wspólnego rynku wykorzystując energię atomową wyłącznie w celach pokojowych (Barcz i in., 2007: 40).

Koncentrując się na procesie integracji w ramach wspólnot należy zaznaczyć, że w dalszym okresie nastąpiła pewnego rodzaju stagnacja w sferze zacieśniania więzi między państwami członkowskimi wspólnot europejskich. Skupiono się bardziej na zwiększaniu terytorium wspólnotowego poprzez przyjmowanie nowych państw w struktury ugrupowania. Na szczycie w Hadze w 1969 roku podjęto decyzję o rozszerzeniu i pogłębieniu dalszej współpracy. W rezultacie w 1970 roku ogłoszono plan Wernera przewidujący wprowadzenie unii gospodarczej i walutowej. W okresie tym rozpoczęto także negocjacje akcesyjne z państwami EFTA, w wyniku których z początkiem 1973 roku nastąpiło pierwsze poszerzenie Europejskiej Wspólnoty Gospodarczej o Wielką Brytanię, Danię oraz Irlandię. W latach 70. XX wieku wdrożono nowe zasady polityki ochrony środowiska i polityki społecznej. Zapowiedzią wprowadzenia rozwijanej do dziś wspólnej polityki regionalnej było stworzenie Europejskiego Funduszu Rozwoju Regionalnego. Powstał również Europejski System Walutowy oraz jednostka pieniężna ECU, co miało wzmacniać stabilność monetarną w państwach członkowskich. W 1981 roku Grecja dołączyła do dziewięciu państw tworzących europejskie wspólnoty, a pięć lat później państwami członkowskimi stały się także Portugalia oraz Hiszpania. Natomiast w 1985 roku podpisano Układ z Schengen, którego celem było stopniowe zniesienie kontroli na wewnętrznych granicach pomiędzy państwami wspólnot, $\mathrm{z}$ równoczesnym wzmocnieniem zewnętrznych kontroli granicznych (Mach i Natanek, 2011: 62-64).

Kolejnym ważnym dla procesu integracji wydarzeniem była znacząca zmiana postanowień traktatów założycielskich wspólnot na skutek ustanowienia w 1986 roku Jednolitego Aktu Europejskiego przygotowującego podstawę do ustanowienia Unii Europejskiej. Z tego względu przewidziano w nim, że do końca 1992 roku utworzony zostanie obszar zapewniający swobodny przepływ osób, kapitału, towarów i usług. Poza tym poszerzono zakres kompetencji wspólnotowych instytucji oraz formalnie ustanowiono Radę Europejską (Sieniow, 2012: 42-43).

Traktat o Unii Europejskiej podpisany w 1992 roku w wyniku szczytu Rady Europejskiej w Maastricht okazał się przełomowy dla istniejących wspólnot europejskich. Wszedł on w życie 1 listopada 1993 roku. Na jego mocy Unia Europejska była złożona strukturalnie z trzech filarów obejmujących: wspólnoty europejskie, wspólną politykę zagraniczną i bezpieczeństwa oraz współpracę w obrębie wymiaru sprawiedliwości i spraw wewnętrznych. Początkowo Unia nie miała osobowości prawnej, a instytucje wspólnot europejskich zapewniały jednolitość jej ram instytucjonalnych. Traktat z Maastricht był równocześnie traktatem rewizyjnym, skutkującym przemianowaniem Europejskiej Wspólnoty Gospodarczej na Wspólnotę Europejską. Ponadto na jego mocy wprowadzono następujące postanowienia: po pierwsze, uzgodniono, że do 1999 roku w Unii Europejskiej 
wprowadzona zostanie wspólna waluta, a uczestnikami unii walutowej będą mogły być wyłącznie te państwa, które spełnią ustalone w traktacie warunki ekonomiczne, zwane kryteriami konwergencji. Utworzony do momentu wprowadzenia wspólnej waluty Europejski Instytut Walutowy miał wykonać prace przygotowawcze, którego funkcje z czasem miał przejąć Europejski Bank Centralny prowadzący jednolitą politykę pieniężną. Mimo, że traktat ten był wynikiem znacznego kompromisu, jednak nie wszystkie państwa członkowskie w pełni zaakceptowały jego zapisy. Przyjęciu wspólnej waluty przeciwna była Wielka Brytania oraz Dania, dlatego zwalniając je z tego obowiązku przyznano im tzw. klauzulę opt-out (Borowiec, 2011: 46-48).

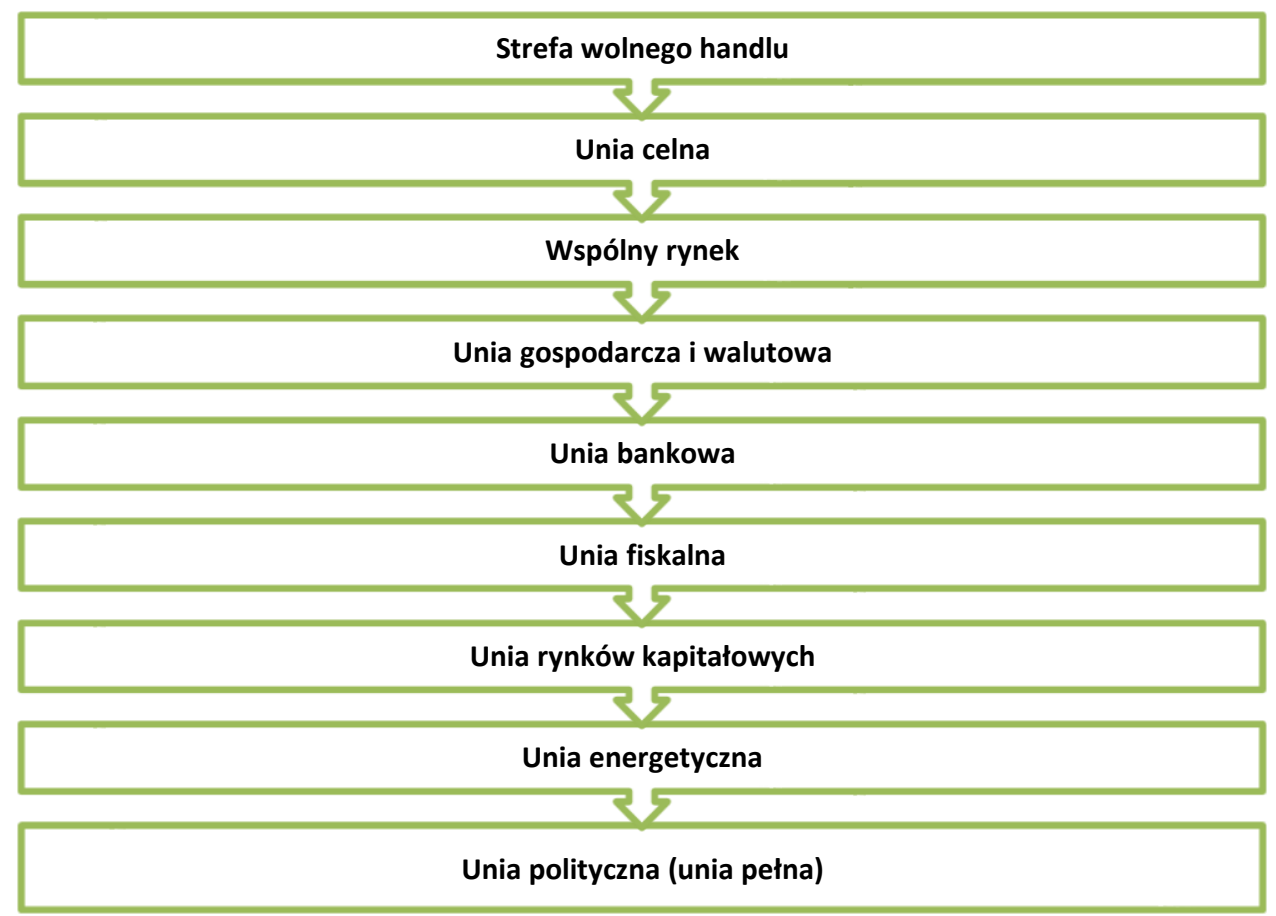

Rysunek 1. Etapy integracji europejskiej

Źródło: opracowanie własne.

W międzyczasie podpisano liczne traktaty, jednak niebagatelne znaczenie dla obecnego kształtu unijnych struktur miał traktat podpisany w wyniku obrad szczytu w Lizbonie w 2007 roku. Udało się go wprowadzić w życie w grudniu 2009 roku. Na mocy Traktatu z Lizbony nazwa Unia Europejska zastąpiła Wspólnotę Europejską. Traktat Lizboński obejmował szereg nowych rozwiązań, 
mających na celu usprawnienie procesu podejmowania decyzji oraz skuteczne działanie Unii. Ostatnie poszerzenie unijnych struktur nastąpiło w 2013 roku, kiedy do grona unijnych państw przyjęta została Chorwacja. Podsumowując dotychczasowe działania warto podkreślić, że na przestrzeni lat następowało wzmacnianie pozycji ponadnarodowych instytucji, choć Unia Europejska wciąż jest organizacją suwerennych państw (Mach i Natanek, 2011: 71-75).

Niewątpliwie integracja jest procesem dynamicznym, polegającym na zacieśnianiu więzi pomiędzy państwami w sposób wielofazowy. Na rysunku 1 zaprezentowano etapy prowadzące do osiągnięcia pełnej integracji państw europejskich.

Pierwszym krokiem prowadzącym do integracji ekonomicznej jest utworzenie przez członków ugrupowanie strefy wolnego handlu. Stanowi ona najprostszą formę integracji, polegającą na eliminacji podstawowych barier handlowych między partnerami, takich jak cła i ograniczenia ilościowe. Przy jednoczesnym zachowaniu autonomii w określaniu stawek celnych i innych instrumentów zagranicznej polityki ekonomicznej w stosunku do państw nieczłonkowskich. Wobec czego mogą być one zróżnicowane, a zagranicznej wymianie towarów i usług z reguły towarzyszy niski stopień harmonizacji polityki handlowej (Bożyk i Misala, 2003: 88-90). Drugą fazą procesu integracji jest unia celna, obejmująca zarówno brak przeszkód w przepływie dóbr w ramach unii, jak i wprowadzenie wspólnej zewnętrznej taryfy celnej i jednolitej polityki handlowej wobec państw trzecich (Borowiec, 2011: 27). Bardziej zaawansowaną formą współpracy jest wspólny rynek uzupełniający wcześniejsze etapy tym, że na jego obszarze zostaje zapewniony swobodny przepływ siły roboczej, kapitału, towarów i usług. Dodatkowo w ramach wspólnego rynku występuje harmonizacja polityk w obszarach kluczowych dla funkcjonowania gospodarek krajów uczestniczących, zwłaszcza w zakresie: transportu, rolnictwa, opodatkowania, konkurencji oraz polityki regionalnej. Dziedziny i zakres wspólnych polityk mogą się różnić, a ich rozległa i głęboka integracja ma prowadzić do powstania rynku wewnętrznego w obrębie państw członkowskich (Nowak-Far, 2011: 2). Kolejnym krokiem na drodze pełnej integracji jest unia gospodarcza i walutowa. Unia gospodarcza jest rozwinięciem wspólnego rynku i polega na koordynacji bądź unifikacji najważniejszych obszarów polityki makroekonomicznej. $Z$ kolei unia walutowa dotyczy powiązania ze sobą walut państw członkowskich przy pomocy nieodwołalnie stałych kursów walutowych lub wprowadzenie jednej wspólnej waluty. Ponadto bez względu na formę integracji walutowej prowadzona jest jednolita polityka pieniężna. Warto podkreślić, że Unia Europejska znajduje się obecnie na tym poziomie integracji, a państwa które przyjęły wspólną walutę twarzą strefę euro (Borowiec, 2011: 27). Strefa euro powstała w wyniku przyjęcia przez część państw Unii Europejskiej wspólnej waluty, którą nazwano euro i oznaczono następującym znakiem graficznym „€”. Obecnie obszar euro tworzy 19 państw Unii Europejskiej, lecz docelowo 
wszystkie państwa zobowiązały się przyjąć wspólną walutę z wyjątkiem Danii i Wielkiej Brytanii, która opuściła unijne struktury w 2020 roku. Kraje pozostające czasowo poza obszarem euro nazywa się państwami z derogacją. W chwili obecnej należą do nich: Szwecja, Polska, Czechy, Węgry, Bułgaria, Rumunia i Chorwacja. Unia gospodarcza i walutowa została utworzona dnia 1 stycznia 1999 roku, wtedy też euro pojawiło się w obiegu bezgotówkowym, jednak do obiegu gotówkowego weszło dopiero z początkiem 2002 roku. Warunki przyjęcia euro nazywane kryteriami zbieżności bądź konwergencji. Zostały one wprowadzone na mocy zapisów Traktatu z Maastricht, a obecnie są szczegółowo określone w Protokole nr 13 do Traktatu o funkcjonowaniu Unii Europejskiej. Zostały one stworzone w celu zapewnienia sprawniejszego funkcjonowania unii walutowej i stanowią one podstawową miarę warunkującą przyjęcie przez dane państwo wspólnej waluty. Kryteria konwergencji nominalnej dotyczą następujących obszarów:

- stabilności cen - oznacza, że średnia roczna stopa inflacji w danym kraju nie powinna przekroczyć o więcej niż 1,5 punktu procentowego inflacji w trzech państwach Unii Europejskiej o najbardziej stabilnych cenach,

- stabilnych i zrównoważonych finansów publicznych - jest to tzw. kryterium fiskalne, według którego deficyt budżetowy nie powinien przekroczyć 3\% produktu krajowego brutto, a dług publiczny rozumiany jako dług sektora instytucji rządowych i samorządowych powinien wynosić mniej niż $60 \%$ produktu krajowego brutto,

- trwałości konwergencji - oznacza, że długoterminowa nominalna stopa procentowa nie może być wyższa niż o 2 punkty procentowe od średniej odpowiednich stóp procentowych w trzech państwach Unii Europejskiej o największej stabilności cen,

- stabilności kursu walutowego - polega na przestrzeganiu przedziału wahań waluty danego państwa w ramach systemu ERM II przez okres przynajmniej dwóch lat poprzedzających ocenę bez możliwości dewaluacji własnej waluty tym okresie.

Ponadto wyróżniono tzw. kryterium prawne w głównej mierze dotyczące niezależności banku centralnego. Dopiero łączne spełnienie powyższych warunków może stanowić podstawę do wejścia danego kraju do strefy euro. Nie wszystkie państwa spełniają powyższe kryteria, a powodów trudności w zakresie ich wypełnienia można upatrywać $\mathrm{w}$ dotychczasowej tolerancji braku dyscypliny w tym zakresie oraz zwyczajnej niechęci po stronie państw z derogacją do uczestnictwa w strefie euro.

Za politykę pieniężną w strefie euro jest odpowiedzialny Europejski Bank Centralny, który powstał w 1998 roku na skutek przekształcenia z utworzonego w 1994 roku Europejskiego Instytutu Walutowego. Europejski Bank Centralny posiada osobowość prawną, a także zdolność prawną oraz zdolność do czynności 
prawnych w każdym z państw członkowskich. Europejski Bank Centralny stanowi główne ogniwo Europejskiego Systemu Banków Centralnych, dlatego podejmuje decyzje i uchwala rozporządzenia niezbędne do wykonania powierzonych mu zadań. Ponadto wydaje zalecenia i opinie oraz odpowiada za emisję banknotów i monet euro. Kapitał Europejskiego Banku Centralnego wynosi ponad 10 mld euro i jest gromadzony przez krajowe banki centralne państw członkowskich Unii Europejskiej według klucza subskrypcji, odpowiadającego sumie połowy udziału danego państwa w łącznej liczbie ludności i połowy udziału danego kraju w produkcie krajowym brutto całej Unii (Barcz i in., 2012: 201-204). Zgodnie z danymi zamieszczonymi na wykresie 1 . od rozpoczęcia kryzysu miały miejsce sukcesywne obniżki stóp procentowych obowiązujących na terenie strefy euro, a od czerwca 2014 roku mamy do czynienia z ujemną wartością stopy depozytowej. Ponadto $\mathrm{w}$ ostatnich latach zauważalnym zjawiskiem jest również zawężenie korytarza zmienności stóp procentowych na rynku międzybankowym.

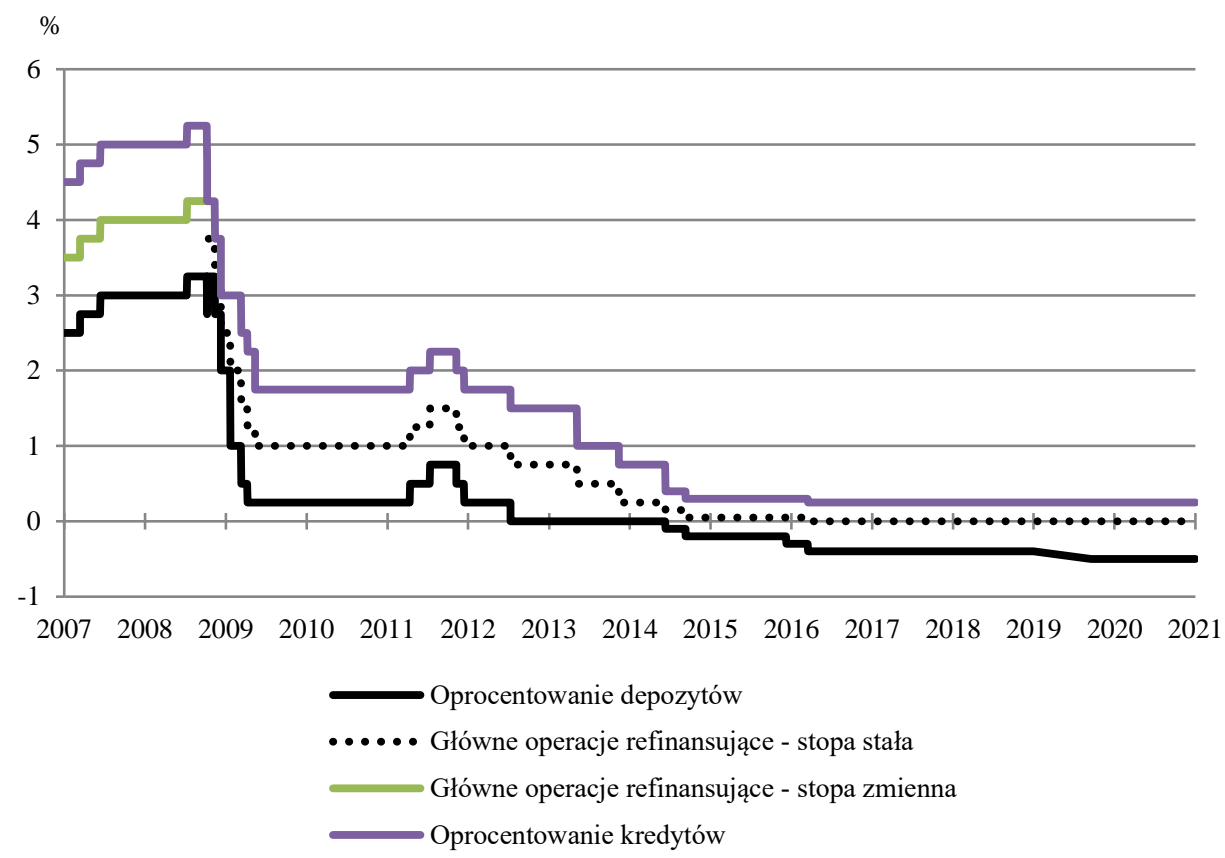

Wykres 1. Polityka stóp procentowych Eurosystemu w latach 2007-2020

Źródło: opracowanie własne na podstawie danych EBC. 


\section{KONCEPCJA UNII BANKOWEJ}

Najważniejszym etapem z punktu widzenia tematu niniejszego artykułu jest stworzenie przez państwa europejskie unii bankowej, mającej na celu wzrost stabilności sektora finansowego. Zgodnie z założeniami ma się ona przejawiać ujednoliceniem zasad funkcjonowania banków poprzez wprowadzenie europejskiego nadzoru bankowego, jednolitego systemu restrukturyzacji i uporządkowanej likwidacji banków oraz wspólnego systemu gwarantowania depozytów (Brudziński, 2012). Pośrednią fazą na drodze do unii politycznej jest także unia fiskalna, której celem jest zwiększenie dyscypliny finansowej wśród nadmiernie zadłużonych państw członkowskich. Projekt unii fiskalnej nosi nazwę zintegrowanych ram budżetowych i obejmuje m.in. stworzenie autonomicznego budżetu dla państw strefy euro, który pozwoliłby na wspólną emisję długu publicznego (KE, 2012). Kolejnym ważnym krokiem zmierzającym w kierunku całkowitej integracji europejskiej jest $\mathrm{z}$ pewnością unia rynków kapitałowych, która miałaby na celu ułatwienie dostępu do kapitału oraz zwiększenie stabilizacji finansowej i atrakcyjności inwestycyjnej Europy. Zgodnie z zapowiedziami projekt ten ma być skierowany do wszystkich państw Unii Europejskiej. Ponadto w przeciwieństwie od unii bankowej unia rynków kapitałowych najprawdopodobniej nie będzie tworzona wokół nowych instytucji nadzoru, gdyż dodatkowe kompetencje planuje się powierzyć Europejskiemu Urzędowi Nadzoru Giełd i Papierów Wartościowych (ESMA) (Michalik, 2014). Polską inicjatywą w zakresie pogłębiania procesu integracji europejskiej jest projekt utworzenia unii energetycznej, która by pozwoliła na uniezależnienie się państw członkowskich od dostaw gazu z Rosji. Ma ona być oparta na pięciu filarach, jednak założenie o wspólnych zakupach gazu od dostawców zewnętrznych wciąż budzi kontrowersje (Soja, 2014). Końcowym etapem przedstawionego procesu ma być pełna integracja polityczna, rozumiana jako dopasowanie wewnętrznej i zagranicznej polityki i integrujących się państw. Unifikacja tych polityk jest zazwyczaj poprzedzona konsultacjami i uzgodnieniem kierunków podejmowanych działań. Pełna integracja cechuje się ponadto całkowitym ujednoliceniem podstawowych zasad i reguł funkcjonowania gospodarki w skali międzynarodowej. Warunkiem stworzenia unii politycznej jest istnienie ponadnarodowej władzy, której decyzje obowiązują kraje członkowskie. Wiąże się to z przekazaniem uprawnień integrujących się państw na szczebel ponadnarodowy (Bożyk i Misala, 2003: 184-196). W świetle zachodzących obecnie wydarzeń o charakterze dezintegracyjnym, związanych $\mathrm{z}$ opuszczeniem przez Wielką Brytanię Unii Europejskiej należy stwierdzić, że aby osiągnąć założony poziom integracji niezbędne jest wprowadzenie reform systemowych oraz podjęcie działań, aby zapobiec dalszym rozłamom w europejskiej wspólnocie.

Doświadczenia kryzysu finansowego z pierwszej dekady XXI wieku spowodowały, że ważnym zagadnieniem stało się zapewnienie bezpieczeństwa systemu 
bankowego. Podstawowym czynnikiem mającym je zapewnić jest istnienie instytucji tworzących sieć bezpieczeństwa. Należą do nich: bank centralny, system gwarantowania depozytów oraz organ nadzoru bankowego. Owe części składowe sieci bezpieczeństwa są również definiowane jako zespół rozwiązań instytucjonalnych i regulacji prawnych, których celem jest ochrona systemu przed destabilizacją, co osiąga się poprzez wzrost jego wiarygodności, zapobieganie kryzysom oraz łagodzenie ich skutków (Koleśnik, 2015: 108-114).

Bezpośrednią przyczyną podjęcia działań zmierzających do utworzenia unii bankowej był kryzys finansowy z przełomu lat 2008-2009, w wyniku którego instytucje finansowe oraz gospodarki wielu państw poniosły olbrzymie straty. W celu zredukowania prawdopodobieństwa wystąpienia kolejnego kryzysu finansowego oraz zwiększenia odporności europejskiego systemu finansowego podjęto szereg inicjatyw i zmian instytucjonalnych w Unii Europejskiej. Do najważniejszych z nich należy wprowadzenie scentralizowanego nadzoru europejskiego nad systemem finansowym, zarówno na poziomie makro-, jak i mikroostrożnościowym. Za nadzór makroostrożnościowy odpowiada Europejska Rada Ryzyka Systemowego (ESRB), której zadaniem jest przede wszystkim identyfikacja zagrożeń dla stabilności systemu finansowego, publikacja ostrzeżeń przed ryzykiem oraz w razie konieczności wydawanie zaleceń w sprawie środków, które powinny zostać podjęte by osłabić określone zagrożenia. Zatem organ ten zajmuje się głównie analizą ryzyka systemowego w państwach Unii Europejskiej. Nowa architektura nadzoru finansowego na szczeblu unijnym została ustanowiona w 2011 roku. W wyniku czego powstały trzy Europejskie Urzędy Nadzoru (ESA) tworzące Europejski System Nadzoru Finansowego, którym powierzono nadzór mikroostrożnościowy. Należą do nich: Europejski Organ Nadzoru Bankowego (EBA), Europejski Organ Nadzoru nad Rynkiem Kapitałowym (ESMA) oraz Europejski Urząd Nadzoru Ubezpieczeń i Pracowniczych Programów Emerytalnych (EIOPA). Ich zadaniem jest ocena sytuacji poszczególnych instytucji na wskazanych rynkach finansowych mająca na celu zapewnienie stabilności systemów finansowych, a także zagwarantowanie ochrony ich klientom (Hryckiewicz i Pawłowska, 2013: 15-16).

W 2012 roku Komisja Europejska uznała, że podejmowane w ostatnich latach działania na szczeblu unijnym okazały się być niewystarczające dla zapewnienia w strefie euro stabilności finansowej. Wspólna europejska waluta z jednej strony spowodowała pobudzenie integracji gospodarczej, a z drugiej strony podwyższyła ryzyko wystąpienia negatywnych konsekwencji transgranicznych kryzysów bankowych. W wyniku działań mających na celu ratowanie banków, które utrzymywały bliskie relacje z państwami macierzystymi w czasie minionego kryzysu wydatkowano w Unii Europejskiej ponad 4,5 bln euro. Pomoc udzielana bankom przez rządy poszczególnych państw sprawiła, że w czasie problemów światowe w swych operacjach banki zaczęły być postrzegane jako narodowe instytucje. 
Zdaniem Komisji Europejskiej sama koordynacja działań między krajowymi organami nadzoru w świetle kryzysu okazała się być niedostatecznie skuteczna. Uznano zatem, że konieczne jest ustanowienie wspólnego procesu decyzyjnego. Argumentem przemawiającym za tego typu rozwiązaniem jest również fragmentacja sektora bankowego, powodująca osłabienie jednolitego rynku usług finansowych oraz ograniczenie wpływu polityki pieniężnej na sferę realną gospodarki strefy euro. Utworzenie unii bankowej miało na celu ograniczenie ryzyka kryzysów bankowych, przerwanie współzależności pomiędzy długiem państwowym, a długiem bankowym oraz przywrócenie zaufania do wspólnej waluty, która stanowi ważny element w procesie długoterminowej integracji ekonomicznej. Działania zmierzające do powstania unii bankowej zostały podjęte na podstawie art. 114 oraz 127 ust. 6 Traktatu o funkcjonowaniu Unii Europejskiej. Dnia 23 maja 2012 roku ówczesny przewodniczący Komisji Europejskiej José Manuel Barroso na nieformalnym posiedzeniu Rady Europejskiej przedstawił koncepcję utworzenia unii bankowej, określanej także mianem zintegrowanych ram finansowych. Zgodnie z opublikowanym w czerwcu 2012 roku sprawozdaniem pod tytułem „W kierunku faktycznej unii gospodarczej i walutowej” unia bankowa obok zintegrowanych ram budżetowych, zintegrowanej polityki gospodarczej oraz dzięki zapewnieniu niezbędnej demokratycznej legitymizacji, przy ścisłym zaangażowaniu parlamentów narodowych i Parlamentu Europejskiego, miały wpływać na przyszły kształt unii (Szpringer, 2013).

Według planu przedstawionego we wrześniu 2012 roku elementami składowymi unii bankowej miały stać się: jednolity system nadzoru bankowego, wspólny mechanizm restrukturyzacji i uporządkowanej likwidacji banków oraz europejski system gwarantowania depozytów konsumentów. Jeszcze w grudniu tego samego roku na szczycie w Brukseli uzgodniono scenariusz stworzenia i funkcjonowania wspólnego systemu nadzoru bankowego. Ustalono również, że następne elementy unii bankowej będą tworzone w dalszej kolejności (Pietrzykowski, 2014: 102). Poza tym podstawą istnienia unii bankowej są nowe ramy regulacyjne ujęte $\mathrm{w}$ jednolitym zbiorze przepisów regulujących zasady funkcjonowania europejskich banków (Single Rulebook), dzięki którym łatwiej będzie można zapobiegać kryzysom bankowym, poprawi się kapitalizacja banków oraz ograniczony zostanie poziom ryzyka systemowego, co ma sprzyjać zwiększeniu stabilności europejskiego systemu finansowego. Piątym składnikiem dopełniającym działanie unii bankowej jest fundusz Europejskiego Mechanizmu Stabilizacyjnego (ESM), którego środki pełnią rolę swoistej sieci bezpieczeństwa w sytuacji konieczności dokapitalizowania banków bez pośrednictwa krajowych budżetów (Brudziński, 2012).

Zgodnie z założeniami unia bankowa ma stanowić kolejny etap procesu integracji europejskiej wspierając i wzmacniając przy tym stabilność finansową. Jednocześnie zintegrowane ramy finansowe mają zapobiec utracie zaufania do 
sektora bankowego oraz przerwać związek między ryzykiem bankowym i budżetowym. Przesunięcie odpowiedzialności za system bankowy na poziom unijny powinno także ograniczyć segmentację rynku finansowego, zredukować przepływy depozytów oraz osłabić zależność pomiędzy wzrostem finansowania banków i kosztów długu publicznego (Chrabonszczewska, 2013: 57).

Do głównych zadań unii bankowej zalicza się (Czajkowska, 2016: 181):

- przerwanie współzależności między sytuacją banków, a zadłużeniem rządów,

- przywrócenie transmisji kredytu do gospodarki,

- zaprzestanie procederu ratowania banków na koszt podatników,

- lepszą integrację rynku kredytowego oraz powrót europejskich banków do ich pierwotnej funkcji, jaką jest udzielanie kredytów.

Pierwszym filarem zintegrowanych ram finansowych nad którym podjęto działania w ramach unii bankowej jest europejski nadzór bankowy, nazywany jednolitym mechanizmem nadzorczym (SSM). Jednolity mechanizm nadzorczy obejmuje Europejski Bank Centralny oraz krajowe organy nadzoru. Przeniesienie kompetencji nadzorczych z poziomu krajowego na poziom europejski oznacza, że nadzór przybiera charakter ponadnarodowy. Stanowi to swego rodzaju novum bowiem dotychczas nawet w stosunku do banków prowadzących działalność transgraniczną sprawowano przede wszystkim nadzór krajowy, który bardziej się sprawdza w odniesieniu do małych banków, ponieważ krajowy nadzorca lepiej zna specyfikę lokalnego rynku. Stąd postanowiono, że Europejski Bank Centralny ma być odpowiedzialny za bezpośredni nadzór nad istotnymi instytucjami kredytowymi w strefie euro. Istotnymi instytucjami kredytowymi są podmioty, które:

- posiadają aktywa o wartości przewyższającej 30 mld euro albo

- posiadają aktywa, które przewyższają 20\% PKB kraju macierzystego i są przy tym wyższe niż 5 mld euro lub

- zostaną uznane przez Europejski Bank Centralny za istotne z jego inicjatywy bądź na wniosek krajowego organu nadzoru oraz

- są instytucjami kredytowymi, które uzyskały albo wystąpiły o przyznanie pomocy ze środków Europejskiego Instrumentu Stabilności Finansowej (EFSF) lub Europejskiego Mechanizmu Stabilności (ESM).

Niezależnie od powyższych kryteriów Europejski Bank Centralny będzie sprawować nadzór nad trzema najbardziej znaczącymi instytucjami kredytowymi z państw uczestniczących w unii bankowej. Jednak objęcie ich unijnym nadzorem nie rozwiązuje do końca problemu związanego $\mathrm{z}$ istnieniem instytucji zbyt dużych, żeby upaść (SIFIs) (Zaleska, 2015: 18-19).

Obowiązek udziału w unii bankowej dotyczy wszystkich państw strefy euro, lecz pozostali członkowie Unii Europejskiej posiadający własną walutę mają możliwość uczestnictwa w opisywanym projekcie korzystając z tzw. klauzuli optin. Warunkiem włączenia ich do unii bankowej jest wyrażenie chęci przystąpienia 
do tego mechanizmu na zasadzie bliskiej współpracy z Europejskim Bankiem Centralnym. Uczestnicy unii bankowej spoza strefy euro będą mogli uczestniczyć w Radzie do spraw Nadzoru, która odpowiada za planowanie oraz realizację zadań nadzorczych przez centralny bank unii walutowej. Europejski Bank Centralny jako podmiot odpowiedzialny za skuteczność i spójność mechanizmu w pełnym zakresie wykonuje zadania związane z nadzorem ostrożnościowym od 4 listopada 2014 roku. Według dostępnych informacji pod bezpośredni nadzór Europejskiego Banku Centralnego podlegało początkowo niemal 130 europejskich banków ważnych systemowo, na które przypadało prawie $85 \%$ aktywów sektora bankowego strefy euro. Jednocześnie blisko 6000 instytucji kredytowych w samej strefie euro pozostało pod nadzorem odpowiednich organów krajowych. $Z$ uwagi na fakt, że są państwa spoza strefy euro, które nie wyrażają chęci przystąpienia do unii bankowej tworząc jednolity mechanizm nadzoru duży nacisk położono na zabezpieczenie tych krajów przed dyskryminacją. Dlatego postanowiono, że Europejski Urząd Nadzoru Bankowego posiadając prawo wiążącej mediacji ma pełnić funkcję gwaranta równego traktowania każdego państwa członkowskiego, przy czym w sytuacjach spornych Europejski Bank Centralny będzie traktowany tak samo jak krajowe organy nadzoru.

W związku z rozszerzeniem zakresu działań Europejskiego Banku Centralnego konieczne stały się zmiany związane z kompetencjami innych organów nadzorczych. Zatem Europejski Urząd Nadzoru Bankowego, do którego zadań należy głównie dążenie do spójnego stosowania jednolitego zbioru przepisów obejmujących kwestie nadzoru nad bankami oraz zwiększenie konwergencji unijnych praktyk nadzorczych. Został on zobligowany do stworzenia Single Rulebook, przez co rozumie się jednolity zbiór przepisów mający na celu harmonizację zasad ostrożnościowych obowiązujących instytucje kredytowe na terenie całej Unii Europejskiej, którego uzupełnieniem miał być Single Supervisory Handbook, czyli europejski podręcznik nadzoru nad instytucjami finansowymi, który ma wskazywać najlepsze praktyki z obszaru metodologii oraz procesów nadzoru. Dodatkowo ten europejski nadzorca bankowy regularnie weryfikuje odporność unijnych banków na sytuacje kryzysowe, publikując raporty na temat oceny ryzyka w tym sektorze (Pawlik, 2014).

W celu zobrazowania skali kosztów będących konsekwencją wprowadzenia pierwszego filaru unii bankowej w tabeli 1 zestawiono wielkość kosztów poniesionych tylko przez Europejski Bank Centralny w latach 2014-2019. Na podstawie zaprezentowanych danych można zauważyć stosunkowo wysoki udział środków przeznaczanych na wynagrodzenia i świadczenia na rzecz pracowników służb wspólnych i pionu nadzoru oraz znaczący wzrost łącznych kosztów z tytułu zadań dotyczących nadzoru bankowego w okresie objętym analizą. Jednak łączna wysokość stałych rocznych kosztów nadzorczych Europejskiego Banku Centralnego może być dokładnie znana dopiero $\mathrm{w}$ średnim okresie. $\mathrm{Z}$ drugiej strony 
łączna kwota opłat pobranych przez Europejski Bank Centralny z tytułu kosztów nadzoru ostrożnościowego nad sektorem bankowym w strefie euro w latach 2014-2015 wyniosła jedyne $326 \mathrm{mln}$ euro. Oznacza to, że koszty poniesione w związku z realizacją zadań nadzorczych $\mathrm{w}$ całości pokryte zostały przez nałożone na nadzorowane podmioty opłaty nadzorcze w 2015 roku, a w 2014 roku bank centralny strefy euro odzyskał $w$ ramach opłat nadzorczych wyłącznie koszty poniesione $\mathrm{z}$ tego tytułu za ostatnie dwa miesiące roku w kwocie $30 \mathrm{mln}$ euro. Dla porównania łączne koszty administracyjne Europejskiego Banku Centralnego wyniosły w 2015 roku $864 \mathrm{mln}$ euro, co oznacza wzrost o $187 \mathrm{mln}$ euro w porównaniu z rokiem poprzednim (EBC, 2016b).

Tabela 1. Koszty pionu nadzoru Europejskiego Banku Centralnego w latach 2014-2019 (mln euro)

\begin{tabular}{|c|r|r|r|r|r|r|}
\hline Rok & \multicolumn{1}{|c|}{2014} & \multicolumn{1}{c|}{2015} & \multicolumn{1}{c|}{2016} & \multicolumn{1}{c|}{2017} & \multicolumn{1}{c|}{2018} & \multicolumn{1}{c|}{2019} \\
\hline Wynagrodzenia i świadczenia & 68,9 & 141,3 & 180,6 & 215,0 & 246,0 & 272,6 \\
\hline Wynajem i utrzymanie budynków & 13,2 & 25,5 & 58,1 & 53,0 & 58,8 & 60,9 \\
\hline Pozostałe koszty operacyjne & 74,8 & 110,3 & 143,4 & 168,8 & 213,0 & 203,5 \\
\hline $\begin{array}{c}\text { Łączne koszty prowadzenia } \\
\text { nadzoru bankowego }\end{array}$ & 156,9 & 277,1 & 382,2 & 436,7 & 517,8 & 537,0 \\
\hline
\end{tabular}

Źródło: opracowanie własne na podstawie danych EBC, 2016a: 76; 2017: 70; 2018: 108; 2019: 90; 2020: 100 .

Oprócz szansy na dalszą integrację finansową oraz wzrost skuteczności nadzoru, w literaturze przedmiotu wymienia się szereg wad jednolitego mechanizmu nadzorczego. Należy do nich fakt, że obowiązek uczestnictwa w SSM obejmuje jedynie kraje należące do strefy euro, gdyż zasięg nadzoru Europejskiego Banku Centralnego nie dotyczy instytucji kredytowych funkcjonujących poza unią bankową, co jeszcze bardziej pogłębia różnice dzielące te grupy państw. Do jego słabości zalicza się również m.in.: możliwość arbitrażu regulacyjnego, rozbudowaną sieć nadzoru nad rynkiem finansowym, czy nakładanie się kompetencji organów nadzorczych. Niemniej jednak kluczowymi kwestiami w ocenie skuteczności organów nadzoru jest ich niezależność i bezstronność (Zielińska-Lont, 2020: 128-130).

Jednolity system restrukturyzacji i uporządkowanej likwidacji banków to drugi ważny komponent, z którego składa się europejska unia bankowa. W skrócie określa się go anglojęzycznym terminem resolution. Rozumie się przez to metodę postępowania wobec banków zagrożonych upadłością, charakteryzującą się z reguły wyeliminowaniem pomocy publicznej, gdyż skutki nieodpowiedniego zarządzania bankiem ponoszą jego udziałowcy oraz wierzyciele. Pierwszym rozwiązaniem w tym zakresie na gruncie europejskim jest przyjęcie dyrektywy dotyczącej restrukturyzacji i uporządkowanej likwidacji banków (BRRD) ustanawiającej 
zharmonizowane ramy procedury resolution dla wszystkich państw członkowskich, które były zobowiązane wprowadzić ją do prawa krajowego przed końcem 2014 roku. Przyjmuje się ogólnie, że procedura resolution powinna być rozpoczynana, gdy bank stoi na progu upadłości bądź jest nią realnie zagrożony. O dyskrecjonalnym charakterze podejmowanych decyzji w zakresie uruchomienia tego procesu może świadczyć fakt, że często odnoszą się one do banków będących w różnych sytuacjach finansowych. Należy przy tym zwrócić uwagę na trudność w jednoznacznym określeniu obiektywnych kryteriów oznaczających, że bank znajduje się w złej sytuacji. Postuluje się aby decyzja ta opierała się zarówno na wskaźnikach ilościowych, jak i na jakościowej ocenie nadzorcy (Szczepańska i in., 2015: 4-6, 45-48).

Koncepcja jednolitego mechanizmu restrukturyzacji i uporządkowanej likwidacji banków została przedstawiona w połowie 2013 roku i od tego czasu mocno ewoluowała. Jej ostateczny kształt znacznie odbiegający od pierwotnych założeń uregulowano w trzech dokumentach: dyrektywie nr 2014/59/UE, rozporządzeniu nr 806/2014/UE oraz umowie międzyrządowej z dnia 21 maja 2014 roku. O ile narzędzia oraz zasady restrukturyzacji i uporządkowanej likwidacji powinny zostać zaimplementowane we wszystkich państwach Unii Europejskiej, o tyle nowe rozwiązania instytucjonalne odnoszą się tylko do uczestników unii bankowej, w tym krajów, które podjęły bliską współpracę w ramach pierwszego filaru zintegrowanych ram finansowych. Jednolita Rada do spraw Restrukturyzacji i Uporządkowanej Likwidacji jest podstawowym organem odpowiedzialnym za przeprowadzanie procesu resolution, w której skład oprócz przewodniczącego wchodzą czterech dodatkowych członków oraz członkowie wyznaczani przez każde państwo uczestniczące będący reprezentantami krajowych organów właściwych do spraw restrukturyzacji i uporządkowanej likwidacji. Rada ta jest odpowiedzialna za opracowywanie planów restrukturyzacji i uporządkowanej likwidacji, a także przyjmowanie decyzji dotyczących restrukturyzacji i uporządkowanej likwidacji, przy czym może ona powierzyć część zadań na poziom krajowy. Jednak we wspomnianym rozporządzeniu przewidziano możliwość powierzenia przez dane państwo uczestniczące w unii bankowej wszelkich kompetencji w zakresie resolution Jednolitej Radzie (Koleśnik, 2015: 99-103).

Przedmiotowy zakres mechanizmu resolution obejmuje działania mające na celu zapobieganie, wczesną interwencję oraz resolution, w ramach którego według dyrektywy nr 2014/59/UE wyróżnia się następujące instrumenty: zbycie działalności, instytucję pomostową, wydzielenie aktywów i umorzenie lub konwersję długu. W podpisanej przez ówczesne kraje Unii Europejskiej - oprócz Szwecji i Wielkiej Brytanii - dnia 21 maja 2014 roku umowie międzyrządowej (IGA) określono zasady finansowania mechanizmu resolution, który co do zasady ma być finansowany $\mathrm{z}$ funduszy sektora prywatnego. Jednak z uwagi na fakt, że środki te mogą okazać się niewystarczające organ resolution powinien 
dysponować zasobami finansowymi umożliwiającymi uzupełnienie tych funduszy. Jednolity fundusz restrukturyzacji i uporządkowanej likwidacji miał być tworzony z gromadzonych sukcesywnie składek. Przystępując do mechanizmu resolution państwa spoza strefy euro będą musiały wpłacić składkę w wysokości zakładającej uczestnictwo w tym mechanizmie danego kraju od początku jego funkcjonowania. Wnoszone ex ante składki z punktu widzenia banków mają być bezzwrotne, ale istnieje możliwość zwrócenia ich państwu kończącemu bliską współpracę w ramach unii bankowej (Zaleska, 2015: 28-30).

Jednolity Fundusz Restrukturyzacji i Uporządkowanej Likwidacji (SRF) jest wyodrębnionym funduszem, zarządzanym przez Jednolitą Radę (SRB), na który składają się banki uczestniczące w unii bankowej. Środki finansowe pochodzące $\mathrm{z}$ tego funduszu mogą być przeznaczone na wsparcie przeprowadzenia procesu resolution. Według pierwotnej koncepcji docelowy poziom SRF, którego osiągnięcie powinno nastąpić do stycznia 2024 roku, został określony jako 1\% depozytów gwarantowanych przez banki działające w unii bankowej, co odpowiada szacunkowej kwocie 60 mld euro (Dobrzańska, 2019).

Pomimo, iż Jednolita Rada do spraw Restrukturyzacji i Uporządkowanej Likwidacji zaczęła funkcjonować już w 2015 roku, nie ma tak ugruntowanej pozycji pośród ponadnarodowych instytucji jak Europejski Bank Centralny, który w głównej mierze odpowiada za unijny nadzór bankowy. W przeciwieństwie do banku centralnego strefy euro Jednolita Rada to agencja z ograniczoną niezależnością, zdolnością do podejmowania decyzji oraz z określonymi zasobami zarówno finansowymi, jak i kadrowymi. W 2015 roku załoga stanowiła w przybliżeniu 120 osób, a budżet wynosił około $12 \mathrm{mln}$ euro, które pochodziły ze składek wpłaconych banki. Natomiast w 2017 roku budżet wynosił wzrósł do 15 mld euro. Wybrany model instytucjonalny SRM oznaczał, że restrukturyzacja i uporządkowana likwidacja częściowo pozostawała w gestii małych banków szczebla krajowego. W odniesieniu do banków znajdujących się pod bezpośrednim nadzorem Europejskiego Banku Centralnego oraz banków transgranicznych, restrukturyzacją i uporządkowaną likwidacją miała zarządzać SRB w zawiłym procesie decyzyjnym, bez znaczącego wsparcia ze strony SRF. W związku z tym w państwach unii bankowej istniały znaczne różnice $\mathrm{w}$ sposobie, $\mathrm{w}$ jaki krajowe władze radziły sobie z zagrożonymi bankami, w szczególności w odniesieniu do kwestii finansowania. Dodatkowo należy zaznaczyć, że w celu kompleksowej oceny funkcjonowania resolution ważne jest całościowe spojrzenie na poszczególne rozstrzygnięcia które będzie możliwe dopiero po pełnym utworzeniu unii bankowej (Quaglia, 2019: 963).

Wspólny system ochrony depozytów ma stanowić trzeci filar europejskiej unii bankowej. Regulacja ta ma służyć ochronie interesu depozytariuszy, zwiększeniu wiarygodności instytucji kredytowych oraz zapobieżeniu pojawiania się paniki $\mathrm{w}$ obliczu kryzysu, a zarazem ma gwarantować, że podmioty, które 
podejmują ryzyko będą za nie odpowiadać. W wąskim ujęciu pojęcie gwarancji depozytów sprowadza się do wypłaty gwarantowanych środków w sytuacji upadku banku. W szerszym ujęciu gwarantowanie wkładów pieniężnych rozumiane jest również jako udzielenie im pomocy w różnych formach. Należy zaznaczyć, że system ten jest już w znacznym stopniu zharmonizowany w Unii Europejskiej, a dalsze zaawansowanie tego procesu powinno przyczynić się do stworzenia bardziej kompletnej unii bankowej. Podczas ostatniego kryzysu w celu przeciwdziałania panice bankowej osiągnięto na poziomie unijnym porozumienie odnoszące się do zmiany systemu gwarancji. Limit gwarancji depozytów podniesiono do wysokości 100000 euro. Natomiast okres wypłaty gwarantowanych środków skrócono do 20 dni roboczych. Wprowadzenie jednolitego systemu ubezpieczenia depozytów zostało przesunięte w czasie, ponieważ uznano, że kwestia ta nie jest pilna, gdyż nie stanowi warunku sprawowania i wykonania nadzoru (Chrabonszczewska, 2013: 66-68).

Ostatni z filarów jest wciąż w fazie koncepcyjnej. Mimo, że uważa się go za niezbędny do dopełnienia unii bankowej, był początkowo nieco zapomniany. W listopadzie 2015 roku podjęto działania w celu stworzenia Europejskiego Systemu Gwarantowania Depozytów (EDIS) polegające na przygotowaniu przez Komisję Europejską projektu rozporządzenia w tej sprawie. Zgodnie z nim europejski system gwarantowania depozytów ma być ustanowiony w trzech kolejnych etapach. W pierwszym z nich trwającym trzy lata miało nastąpić stworzenie systemu reasekuracji krajowych systemów gwarantowania depozytów.

W drugim etapie trwającym cztery lata miało mieć miejsce stworzenie systemu koasekuracji krajowych systemów gwarantowania depozytów. W końcowym etapie przewidywano pełne zabezpieczenie krajowych systemów gwarantowania depozytów. Ten wniosek ustawodawczy zakłada stopniowy proces zwiększania wzajemnej asekuracji uczestniczących systemów gwarantowania depozytów, w efekcie którego ostatecznie zostanie utworzony jednolity system gwarantowania depozytów ograniczający powiązania między bankami, a ich rządami państwowymi. Zawiera on jasny plan działania oraz harmonogram ze ściśle zdefiniowanymi i wyodrębnionymi etapami przejściowymi (reasekuracji i koasekuracji) na drodze do w pełni operacyjnego europejskiego systemu gwarantowania depozytów, czyli do pełnego zabezpieczenia przewidzianego na rok 2024 (Opinia Europejskiego Banku Centralnego z dnia 20 kwietnia 2016 r...: 2).

Chociaż dyrektywę Deposit Guarantee Scheme (DGS) w bardzo okrojonej formie uchwalono już w 2014 roku, to państwa Unii nie osiągnęly zgody, co do wysokości funduszy gwarancyjnych. Początkowe propozycje przewidywały, że będzie to $1,5 \%$ depozytów w ciągu 10 lat, a fundusz ten miał mieć ogólnoeuropejski charakter. W końcu jednak ustalono, że będzie on wynosił $0,8 \%$ gwarantowanych depozytów, czyli około 43 mld euro do 2024 roku, a więc w ciągu ośmiu lat od rozpoczęcia tworzenia go ze składek banków, których wysokość ma być 
zależna od profilu ryzyka banku. Fundusze będą krajowe, a rządy będą mogły porozumiewać się ze sobą w sprawie wzajemnych transferów środków (Ramotowski, 2016).

Po modyfikacji pierwotnych założeń projektu utworzenia wspólnego systemu gwarantowania depozytów przyjęto zasadę mówiącą, że z reasekuracji bądź pełnej asekuracji w ramach trzeciego filaru unii bankowej mogłyby korzystać jedynie krajowe systemy gwarantowania depozytów, które zgromadziłyby we własnym zakresie środki finansowe stanowiące ustalony procent środków gwarantowanych wynoszący od co najmniej $0,05 \%$ na dzień 3 lipca 2017 roku do $0,4 \%$ na dzień 3 lipca 2024 roku. Środki wnoszone do wspólnego funduszu gwarancyjnego przez państwa uczestniczące stanowiłyby zatem połowę zagregowanej kwoty wynikającej z docelowego poziomu zabezpieczenia depozytów określonego na minimalnym poziomie wynoszącym $0,8 \%$. Wśród głównych przyczyn opóźnienia prac w zakresie wdrożenia jednolitego mechanizmu dotyczącego europejskiego systemu gwarancji depozytów najczęściej wymienia się (Lipiński, 2019):

- zróżnicowany status systemów gwarantowania depozytów w krajach członkowskich przed wprowadzeniem w życie przyjętej w 2014 roku unijnej dyrektywy 2014/49/WE, w tym na przykład odmienne poziomy zabezpieczenia obliczane jako relacja kwoty zgromadzonych w funduszu środków do wolumenu chronionych depozytów,

- różny termin rozpoczęcia wdrożenia wyżej wymienionej dyrektywy w poszczególnych państwach, skutkujący między innymi zróżnicowanym tempem dochodzenia do poziomu zabezpieczenia $\mathrm{w}$ docelowej wysokości,

- niechęć instytucji finansowych z krajów o stosunkowo niższym poziomie ryzyka systemowego do przyjmowania dodatkowych obciążeń finansowych,

- wyrażana, szczególnie przez kraje o większym wolumenie depozytów opinia, iż wspólny system gwarantowania wzbudzi efekt hazardu moralnego, który zdemotywuje zarządzających zagrożonymi bankami zwłaszcza z południowej części strefy euro do wysiłków na rzecz restrukturyzacji.

Głównymi dziedzinami planu działania dotyczącego ukończenia budowy unii bankowej w ramach Unii Europejskiej są: europejski system gwarantowania depozytów, wspólny mechanizm ochronny dla jednolitego funduszu restrukturyzacji i uporządkowanej likwidacji oraz bankowe uregulowania służące zmniejszeniu ryzyka. Zdaniem byłego przewodniczącego Eurogrupy Jeroen'a Dijsselbloem'a wynikiem podjętych prac „powinna być odporniejsza unia bankowa, która wzmocni stabilność finansową w strefie euro i w całej Unii Europejskiej. Oczekiwania są duże, bo unia bankowa to jeden $\mathrm{z}$ największych unijnych sukcesów, który znacznie przyczynił się do odbudowy zaufania" (CONSILIUM 2).

Bez wątpienia postępy osiągnięte $\mathrm{w}$ ciągu ostatniej dekady w procesie integracji europejskiej przyczyniły się do zwiększenia stabilności finansowej. Pomogły również w utrzymaniu finansowania gospodarki w czasie ostatniego kryzysu 
wywołanego pandemią. W wyniku problemów finansowych związanych z COVID-19 na szczeblu unijnym podjęto szereg działań mających na celu wzmocnienie odporności strefy euro i jej zdolności do rozwiązywania kryzysów. Jednym $\mathrm{z}$ nich jest uzgodniona pod koniec listopada 2020 roku reforma porozumienia o Europejskim Mechanizmie Stabilności. Jego ratyfikacja ma spowodować, że mechanizm ten stanie się zabezpieczeniem dla SRF od początku 2022 roku, czyli dwa lata przed pierwotnie zaplanowanym terminem. Ponadto w 2021 roku Komisja Europejska ogłosiła przegląd dyrektywy dotyczącej gwarancji depozytów pod kątem ram zarządzania kryzysowego w bankach oraz ubezpieczenia depozytów, która obejmuje dyrektywę w sprawie drugiego filaru unii bankowej (CONSILIUM 1).

W opinii autora przełomem w dalszym kształtowaniu integracji mogą okazać się skutki występującego obecnie kryzysu ekonomicznego. Niemniej jednak wskazane jest podjęcie dalszych działań na rzecz wzmocnienia unii bankowej w celu minimalizacji ryzyka bankowego i ograniczenia oddziaływania jego negatywnych skutków.

\section{PODSUMOWANIE}

Unia bankowa jest kolejnym etapem prowadzącym do osiągnięcia pełnej integracji europejskiej. Z jednej strony unia bankowa ma na celu zwiększenie stabilności i bezpieczeństwa sektora finansowego w Unii Europejskiej. $Z$ drugiej strony jest to projekt polityczny, którego zadaniem jest ujednolicenie różnych unijnych polityk. Unia bankowa w obecnym kształcie ma szeroki zakres kompetencji przejawiający się $\mathrm{w}$ aspekcie prawotwórczym, polegającym na tworzeniu regulacji oraz w wymiarze egzekucyjnym, wyrażającym się w sprawowaniu przez Europejski Bank Centralny bezpośredniego nadzoru nad wybranymi europejskimi grupami bankowymi. Niezależnie od statusu poszczególnych państw spoza strefy euro zintegrowane ramy finansowe chociażby w sposób pośredni będą oddziaływać na wszystkie państwa Unii Europejskiej.

Zgodnie z głównym celem artykułu dokonano oceny znaczenia unii bankowej dla procesu europejskiej integracji. $Z$ poczynionej analizy wynika, że unia bankowa w obecnej postaci nie jest tylko zmianą technokratyczną, ale także elementem nowego porządku politycznego, który wyznacza nowe zasady funkcjonowania nie tylko instytucji finansowych, ale też należących do niej państw i ich systemów politycznych.

Na postawie podjętych rozważań sfomułowano następujący wniosek: unia bankowa jest kluczowym elementem integracji europejskich systemów bankowych oraz stanowi niezbędny etap w kierunku dalszej integracji europejskiej, ponieważ przyczynia się do pogłębienia unii gospodarczej i walutowej. Jednak 
nawet pełne wdrożenie projektu unii bankowej nie gwarantuje całkowitego braku możliwości wystąpienia kryzysów bankowych, lecz może jedynie w pewnym stopniu zredukować to ryzyko, a co za tym idzie ograniczyć koszty tych kryzysów. Unia bankowa jest zatem efektem kompromisu pomiędzy potrzebą wsparcia sektora bankowego strefy euro, a bardziej skoordynowaną kontrolą tego sektora.

Pozytywnie można ocenić pomysł wdrożenia trzeciego filaru unii bankowej, ponieważ system gwarantowania depozytów stanowi uzupełnienie dla wprowadzonych wcześniej mechanizmów unii bankowej. Dzięki temu unia bankowa będzie mogła sprawniej działać. Dopóki unia bankowa nie zostanie w pełni zaimplementowana biorąc pod uwagę bieżące rozwiązania duża część decyzji zostanie przeniesiona na poziom europejski, a koszty funkcjonowania unii bankowej pozostaną na krajowym poziomie.

Podsumowując, należy stwierdzić, że wprowadzone dotąd nowe rozwiązanidotyczące sprawowania unijnego nadzoru finansowego oraz restrukturyzacji i uporządkowanej likwidacji banków, a także wspólnego systemu gwarantowania depozytów są ważnym krokiem prowadzącym do zwiększenia integracji gospodarczej w Europie. Z drugiej strony jest to długotrwały proces, a dokończenie unii bankowej wymaga także unormowania szeregu innych kwestii, takich jak: usunięcie barier dla transgranicznego przepływu kapitału, harmonizacja prawa upadłościowego i postępowań restrukturyzacyjnych, wprowadzenie zmian w zakresie regulacyjnego traktowania ekspozycji banków na dług rządowy, większa koordynacja $w$ ramach przeciwdziałania terroryzmowi oraz praniu brudnych pieniędzy, czy zapewnienie płynności w resolution. Wydaje się, powyższe zagadnienia mające na celu dalsze ograniczenia ryzyka w sektorze bankowym będą przedmiotem prac na unijnym poziomie podczas najbliższych lat.

\section{BIBLIOGRAFIA}

Bańkowski, A. (2000). Etymologiczny stownik języka polskiego. Warszawa: Wydawnictwo Naukowe PWN.

Barcz, J., Górka, M. i Wyrozumska, A. (2012). Instytucje i prawo Unii Europejskiej. Podręcznik dla kierunków prawa, zarzadzania i administracji. Warszawa: LexisNexis.

Barcz, J., Kawecka-Wyrzykowska, E. i Michałowska-Gorywoda, K. (2007). Integracja europejska. Warszawa: Wolter Kluwer business.

Borowiec, J. (2011). Ekonomia integracji europejskiej. Wrocław: Wydawnictwo Uniwersytetu Ekonomicznego we Wrocławiu.

Bożyk, P. i Misala, J. (2003). Integracja ekonomiczna. Warszawa: PWE.

Brudziński, G. (2012). Cztery filary unii bankowej. Bank, 10(237), ss. 14-17.

Chrabonszczewska, E. (2013). Europejska unia bankowa a stabilność finansowa w strefie euro. W: Z. Binek, P. Szudra, red., Integracja walutowa. Zielona Góra: Oficyna Wydawnicza Uniwersytetu Zielonogórskiego, ss. 57, 66-68.

CONSILIUM 1, https://www.consilium.europa.eu/en/policies/banking-union/risk-reduction-european-deposit-insurance-scheme/ [dostęp 01.02.2021]. 
CONSILIUM 2, https://www.consilium.europa.eu/pl/meetings/ecofin/2016/06/17/ [dostęp 24.07.2016].

Czajkowska, A. (2016). Dylematy dla polski związane z przystąpieniem do unii bankowej. Studia Prawno-Ekonomiczne, t. CI, s. 181.

Dobrzańska, A. (2019). 5 lat unii bankowej. Doświadczenia i wyzwania na przyszłość, https://www.obserwatorfinansowy.pl/tematyka/rynki-finansowe/bankowosc/5-lat-unii-bankowej-doswiadczenia-i-wyzwania-na-przyszlosc/ [dostęp 04.02.2020].

EBC, (2016a). Raport roczny EBC z działalności nadzorczej 2015, Marzec 2016, Europejski Bank Centralny, https://www.bankingsupervision.europa.eu/ecb/pub/pdf/ssmar2015.pl.pdf [dostęp 17.07.2016].

EBC, (2016b). Sprawozdanie finansowe EBC za rok 2015. Komunikat Prasowy z 18 lutego 2016 roku, https://www.ecb.europa.eu/press/pr/date/2016/html/pr160218.pl.html [dostęp 17.07.2016].

EBC, (2017). Raport roczny EBC z działalności nadzorczej 2016, Marzec 2017, Europejski Bank Centralny, https://www.bankingsupervision.europa.eu/press/publications/annual-report/html/ssm.ar2016.pl.html [dostęp 21.08.2017].

EBC, (2018). Raport roczny EBC z działalności nadzorczej 2017, Marzec 2018, Europejski Bank Centralny, https://www.bankingsupervision.europa.eu/press/publications/annual-report/html/ssm.ar2017.pl.html [dostęp 02.02.2019].

EBC, (2019). Raport roczny EBC z działalności nadzorczej 2018, Marzec 2019, Europejski Bank Centralny, https://www.bankingsupervision.europa.eu/press/publications/annual-report/html/ssm.ar2018 927cb99de4.pl.html [dostęp 01.06.2019].

EBC, (2020). Raport roczny EBC z działalności nadzorczej 2019, Marzec 2020, Europejski Bank Centralny, https://www.bankingsupervision.europa.eu/press/publications/annual-report/html/ssm.ar2019 4851adc406.pl.html [dostęp 28.03.2020].

EBC, https://www.ecb.europa.eu/stats/policy_and_exchange_rates/key_ecb_interest_rates/html/index.en.html [dostęp 24.01.2021 r.].

Hryckiewicz, A. i Pawłowska, M. (2013). Czy nowy nadzór spełni swoje zadanie? Zmiany w nadzorze finansowym w Europie oraz ich konsekwencje dla Polski. Materiały $i$ studia, 289, ss. 15-16.

Koleśnik, J. (2015). Jednolity mechanizm restrukturyzacji i uporządkowanej likwidacji. W: M. Zaleska, red., Europejska unia bankowa. Warszawa: Difin, ss. 99-103,108-114.

Komisja Europejska [KE], (2012). Plan działania na rzecz pogłębionej i rzeczywistej unii gospodarczej $i$ walutowej (UGW): poczatek europejskiej debaty. Komunikat prasowy z dnia 28 listopada 2012 roku, http://europa.eu/rapid/press-release_IP-12-1272_pl.htm [dostęp 10.07.2016].

Lipiński, Cz. (2019). Tworzenie Europejskiego Systemu Gwarantowania Depozytów. Bezpieczny Bank, 1(74), ss. 44, 50-52.

Łastawski, K. (2011). Historia integracji europejskiej. Toruń: Wydawnictwo Adam Marszałek.

Mach, Z. i Natanek, M. (2011). Historyczny wymiar integracji europejskiej. W: K.A. Wojtaszczyk, red., Integracja europejska. Warszawa: Wydawnictwo Poltext, ss. 47, 53-54, 62-64, 71-75.

Michalik, J. (2014). Kolejna unia? Bank, 11(260), ss. 10-12.

Nowak-Far, A. (2011). Unia Gospodarcza $i$ Walutowa w Europie. Warszawa: Instytut Wydawniczy EuroPrawo.

Opinia Europejskiego Banku Centralnego z dnia 20 kwietnia 2016 r. w sprawie projektu rozporządzenia Parlamentu Europejskiego i Rady zmieniającego rozporządzenie (UE) nr 806/2014 w celu ustanowienia europejskiego systemu gwarantowania depozytów (CON/2016/26), Dz.U. UE, C.2016.252.1.

Pawlik, K. (2014). Kompetencje organów w ramach SSM. Bank, 1(251), ss. 12-14.

Pietrzykowski, M. (2014). Polska na drodze do reformowanej strefy euro. Poznań: Bogucki Wydawnictwo Naukowe. 
Protokół nr 13 do Traktatu o funkcjonowaniu Unii Europejskiej w sprawie kryteriów konwergencji, Dz.U. UE, C.2016.202.281.

Quaglia, L. (2019). The politics of an 'incomplete' Banking Union and its 'asymmetric' effects. Journal of European Integration, 41(1), s. 963.

Ramotowski, J. (2016). Będzie trzeci filar unii bankowej, https://www.obserwatorfinansowy.pl/tematyka/bankowosc/bedzie-trzeci-filar-unii-bankowej/ [dostęp 23.07.2016].

Sieniow, T. (2012). Geneza i rozwój procesów integracyjnych w Europie po II wojnie światowej. W: A. Kuś, red., Prawo instytucjonalne Unii Europejskiej. Lublin: Wydawnictwo KUL, ss. $31-32,42-43$.

Soja, M. (2014). Unia energetyczna, http://www.dyplomacja.org/index.php/pl/analizy/245-uniaenergetyczna.html [dostęp 10.07.2016].

Szczepańska, O., Dobrzańska, A. i Zdanowicz, B. (2015). Resolution, czyli nowe podejście do banków zagrożonych upadłościa. Warszawa: Departament Stabilności Finansowej, Narodowy Bank Polski.

Szpringer, Z. (2013). Unia bankowa. Infos. Biuro Analiz Sejmowych, 8(145), ss. 1-4.

Zaleska, M. (2015). Zintegrowane ramy finansowe - koncepcja i wyzwania. W: M. Zaleska, red., Europejska unia bankowa. Warszawa: Difin, ss. 18-19, 28-30.

Zielińska-Lont, K. (2020). Unia bankowa i jej znaczenie dla funkcjonowania sektora bankowego Unii Europejskiej. Łódź: Wydawnictwo Uniwersytetu Łódzkiego.

\section{ROLA UNII BANKOWEJ W PROCESIE INTEGRACJI EUROPEJSKIEJ}

\section{Streszczenie}

Głównym celem niniejszego artykułu jest ocena wpływu unii bankowej na kształtowanie procesu integracji na kontynencie europejskim. Zostało to dokonane poprzez umiejscowienie unii bankowej jako etapu prowadzącego do pełnej unii państw europejskich. Podstawowe pytanie badawcze niniejszego opracowania zostało sformułowane w następujący sposób: czy projekt unii bankowej jest istotnym elementem przyczyniającym się do pełnej integracji unijnych systemów bankowych, którego realizacja jest niezbędna w celu ochrony Unii Europejskiej przed skutkami przyszłych kryzysów bankowych? Kwestia ta została rozstrzygnięta na podstawie analizy dostępnej literatury oraz danych statystycznych. Podstawowy wniosek wynikający z podjętych badań brzmi następująco: unia bankowa stanowi niezbędny etap w kierunku dalszej integracji europejskiej i jest kluczowym elementem integracji europejskich systemów bankowych. Jednakże nawet pełne wdrożenie projektu unii bankowej całkowicie nie wyeliminuje możliwości wystąpienia kryzysów bankowych, lecz może w pewnym stopniu ograniczyć to ryzyko, a tym samym zredukować koszty potencjalnych kryzysów.

Słowa kluczowe: unia bankowa, integracja europejska, strefa euro. 